\title{
Potential Anticancer Activity of Crude Ethanol, Ethyl Acetate, and Water Extracts of Ephedra foeminea on Human Osteosarcoma U2OS Cell Viability and Migration
}

\author{
Eric Zadok Mpingirika $\mathbb{D}^{\mathbb{D}},{ }^{1}$ Ahmed El Hosseiny $\mathbb{D}^{\mathrm{D}}{ }^{2}$ Sheri Magdy Saleeb Bakheit $\mathbb{D}^{1}{ }^{1}$ \\ Rami Arafeh (iD), ${ }^{3}$ and Asma Amleh (iD) \\ ${ }^{1}$ Biotechnology Program, American University in Cairo, New Cairo 11835, Egypt \\ ${ }^{2}$ Department of Biology, American University in Cairo, New Cairo 11835, Egypt \\ ${ }^{3}$ Palestine-Korea Biotechnology Center, Palestine Polytechnic University, Hebron, State of Palestine \\ Correspondence should be addressed to Asma Amleh; aamleh@aucegypt.edu
}

Received 1 February 2020; Accepted 8 June 2020; Published 9 July 2020

Academic Editor: Giandomenico Roviello

Copyright (C) 2020 Eric Zadok Mpingirika et al. This is an open access article distributed under the Creative Commons Attribution License, which permits unrestricted use, distribution, and reproduction in any medium, provided the original work is properly cited.

\begin{abstract}
Medicinal plants are potential sources for a wide range of complex compounds with probable anticancer activity. Ephedra foeminea Forssk. (E. foeminea), a medicinal plant found in the Eastern Mediterranean, has recently been gaining popularity as a cancer remedy; there is, however, a paucity of empirical evidence supporting this claim. In this study, the effect of E. foeminea ethyl acetate, ethanol, and water crude extracts on viability, migratory ability, and the steady-state mRNA levels of genes involved in these processes was, respectively, examined using MTT assay, wound healing assay, and reverse transcriptase PCR (RT-PCR). The study concludes that all extracts significantly reduce human osteosarcoma U2OS percentage viability in a dose- and timedependent manner, with varying potencies. The least half-maximal inhibitory concentration $\left(\mathrm{IC}_{50}\right)$ was observed in the water extract after $48 \mathrm{~h}$ incubation $(30.761 \pm 1.4 \mu \mathrm{g} / \mathrm{mL})$ followed by the ethyl acetate extract after $72 \mathrm{~h}$ incubation $(80.35 \pm 1.233 \mu \mathrm{g} / \mathrm{mL})$ and finally the ethanol extract after $48 \mathrm{~h}$ incubation $(97.499 \pm 1.188 \mu \mathrm{g} / \mathrm{mL})$. Ethanol extract significantly reduced U2OS percentage wound closure. On the other hand, both ethanol and water extracts considerably reduced the steadystate mRNA expression of beta-catenin, promoting both cell proliferation and migration in osteosarcoma by regulating target genes. Additionally, E. foeminea showed no hemolytic activity. These effects suggest that E. foeminea decreases U2OS cell viability and migratory ability by modulating the expression of critical genes involved in regulating these processes and is likely cytocompatible with human erythrocytes.
\end{abstract}

\section{Introduction}

Accounting for approximately a sixth of all deaths worldwide, the World Health Organization ranks cancer as the second leading cause of death in the world. With 14 million new cases recorded in 2012, a $70 \%$ increase in such incidences is expected within the next twenty years [1]. Despite the progress made in developing cancer treatment procedures, contemporary cancer remedies including surgery and chemoand radiotherapy remain both expensive and ineffective; they pose several adverse side effects to patients, along with the development of drug resistance [2].
Osteosarcoma is the most common primary malignant bone tumor prevalent in both children and adolescents. It accounts for approximately $5 \%$ of all pediatric malignancies and has a global incidence of about 4.5 cases per 1 million individuals annually. Osteosarcoma treatment is administered through a combination of both surgery and chemotherapy, with patient survival rates of about 70\% [3]. The U2OS human osteosarcoma cell line utilized in this study has been reported to be moderately differentiated, with highly altered chromosomes that exist in the hypertriploid range [4].

Several markers involved in cell proliferation, migration, and apoptosis have been implicated in osteosarcoma. In this 
study, the expression of beta-catenin, a key regulator of proliferation in osteogenic cells, was assessed, and its steady-state mRNA is shown to be downregulated by E. foeminea. Betacatenin is regulated by the Wnt signaling cascade in which Wnt glycoproteins bind both Frizzled receptors and LRP 5/6 coreceptors starting a cascade which through disheveled ultimately leads to phosphorylation of the beta-catenin destruction complex. Phosphorylation marks beta-catenin for degradation and vice versa; unphosphorylated beta-catenin migrates to the nucleus and acts as a coactivator, promoting the transcription of several downstream oncogenes such as c-Myc and cyclinD1. Accordingly, aberrant, Wnt signaling significantly contributes to the development of several forms of cancer, including osteosarcoma. Studies have further shown that beta-catenin is relatively highly expressed in osteosarcoma [5].

RUNX2, another marker involved in osteosarcoma, was examined. RUNX2 is a transcription factor that is a primary regulator of both osteogenic differentiation and proliferation. As a controller of both differentiation and growth, RUNX2 expression has been shown to inhibit the proliferation of both normal osteoprogenitor and preosteoblast cells at the late G1 phase of the cell cycle. On the other hand, however, reports revealed that RUNX2 equally promotes cell proliferation in the early G1 phase [6]. RUNX2's promotion or inhibition of cell proliferation has thus been shown to be cell type-specific; whereas RUNX2 mainly inhibits growth in both osteoprogenitor and preosteoblast cells, it has been shown to promote cell proliferation in chondrocytes of RUNX2 null mice [7]. Further still, aortic endothelial cells showed increased proliferation when RUNX2 was ectopically expressed [8]. Such a dual functionality of RUNX2 thus suggests that RUNX2 protein could act as either a tumor suppressor or an oncoprotein. Osteosarcoma biopsies having high RUNX2 expression have been shown to have adverse tumor characteristics such as greater tumorigenicity, tumor progression, and metastases and have further been shown to regulate several cancer-related genes [6].

Key to the success of cancer drug therapies is their ability to induce programmed cell death in cancer cells. The effect of E. foeminea extracts on genes involved in apoptosis was thus assessed. BAX and p53 are two genes that play critical roles in regulating apoptosis. Most drugs that induce apoptosis do so via the intrinsic apoptotic pathway in which apoptosis is initiated by intracellular signals that ultimately lead to the opening of the mitochondrial inner membrane, loss of potential at the mitochondrial transmembrane, and finally release of proapoptotic proteins into the cytoplasm. These mitochondrial changes are regulated by the Bcl- 2 protein family, which is composed of both pro- and antiapoptotic members [9]. BAX belongs to the proapoptotic group of the $\mathrm{Bcl}-2$ family. Reports suggest that the expression of Puma, a Bcl-2 family member, is induced by $\mathrm{p} 53$ and that its overexpression most probably mediates BAX expression, structural change, and mitochondrial translocation, in addition to both the release of cytochrome $c$ and mitochondrial membrane potential reduction. Other reports have further shown that p53 can directly activate BAX and initiate apoptosis [10].

Bioactive compounds are defined as compounds that exert either a positive or negative physiological effect on aliving system. Plant-derived compounds have been reported to alleviate several medical conditions, including inflammation, osteoporosis, and neurodegenerative diseases, in addition to a variety of chronic illnesses such as hypertension, diabetes mellitus, and cancer [11-13]. Medicinal plants are, therefore, a potential source of diverse and complex compounds such as flavonoids, phenols, alkaloids, lectins, and terpenes, which may possess probable anticancer properties [14]. Broadly, the anticancer activity of herbal medicines may be classified into two groups depending on their mode of action. These include immunomodulatory and chemopreventive plants. While immunomodulatory herbs boost the immune system's capability to recognize and eliminate tumor cells, chemopreventive herbal medicines on the other hand utilize complex bioactive compounds to interfere with tumor development via several mechanisms including apoptosis induction, inhibition of nucleic acid synthesis, topoisomerase inhibition, microtubule interference, and cell cycle alteration [14]. As of 2014, 90 out of 121 drugs approved for cancer treatment were associated with herbal plants. To add, studies show that between 1981 and 2002, 48 out of 65 newly registered cancer drugs were obtained from natural products, of which $25 \%$ were associated with medicinal plants [15].

Ephedra foeminea Forssk. (Ephedraceae) is a small evergreen climbing or hanging shrub, distributed in the Eastern Mediterranean region, mostly in montane zones [16]. The plant has tiny scale-like leaves $(2.0 \mathrm{~mm})$ with nonsucculent, spineless stems. Plants in the genus have been utilized as a source of Ephedra alkaloids that act as stimulants, weight loss agents, and dietary supplements. Ephedra alkaloids have however been reported to be associated with psychosis, severe depression, agitation, hallucinations, sleep disturbance, suicidal ideation, and several addiction symptoms [17]. The alkaloids have also been shown to cause stroke and heart problems, prompting a ban in the United States of drugs containing Ephedra, in 2004. Ephedra alkaloids were however not detected in E. foeminea [18].

Although little is known about the use of E. foeminea to treat cancer, its use among Middle Eastern patients recently became popular due to the belief that the herb possesses curative properties against cancer [19]. Ben-Arye and colleagues reported that the boiled water extract of $E$. foeminea showed no significant effect on MDA-MB231 and SKBR3 breast cancer cell lines [19]. However, another study [20] showed that E. foeminea ethanol, water, and fruit juice extracts reduced the percentage viability of these cell lines to varying degrees. Further still, the study reported similar observations when A549 lung carcinoma and HCT116 colorectal carcinoma cells were treated with $E$. foeminea herbal extracts [20]. The discrepancy in the results obtained by these studies thus warrants further investigation into E. foeminea's claimed anticancer properties.

This study hypothesized that E. foeminea ethyl acetate, ethanol, and water extracts significantly affect U2OS cell viability and migration and the expression of genes involved in each of these processes. The main aim of this study was to assess the effect of E. foeminea ethyl acetate, ethanol, and water extracts on morphology, viability, migration, and gene expression of U2OS osteosarcoma cells. 
The first step implemented in the isolation of bioactive compounds is extraction. The yield of bioactive natural products tends to be relatively low and is greatly affected by the extraction method of choice [21]. The type of extraction method employed may further affect the chemical properties of resulting extracts [22]. Based on the extraction principle, methods of extraction include distillation, pressing, sublimation, and solvent extraction; among these, solvent extraction is the most commonly used method. Its extraction efficiency may be affected by the extraction-solvent properties, raw material particle size, solvent ratio to solid, temperature, and duration of extraction [21]. Subsequently, this study utilized a method of solvent extraction called maceration for crude extract preparation. Maceration involves soaking the ground plant material in a solvent and letting the mixture stand at room temperature with frequent agitation until all soluble matter is dissolved; this is followed by pressing the solid residue and filtering the total resulting liquid [23]. Although maceration may be time-consuming, it is a simple procedure and is suitable for extracting thermolabile compounds [21].

In this study, E. foeminea crude extracts were prepared using ethyl acetate (EtOAc), ethanol (EtOH), and water $\left(\mathrm{H}_{2} \mathrm{O}\right)$ as solvents. The effect of each extract on the viability of U2OS osteosarcoma cells was determined using MTT assay while the wound healing assay was employed to study the extracts' effect on U2OS cell migration ability. Differential gene expression of several markers such as beta-catenin (B-catenin), Twist-1, and RUNX2 that regulate key pathways involved in both cell proliferation and migration was tested. All extracts tested in this study significantly reduced U2OS cell viability in a manner dependent on both dose and time. In addition, the ethanol extract significantly reduced U2OS migration ability. All extracts downregulated the steadystate mRNA expression of several genes involved in both cell proliferation and migration, with statistically significant effects observed for both ethanol and water extracts. The hemolysis assay employed to test E. foeminea extract hemolytic activity showed a negligible effect of both ethanol and water extracts on erythrocyte lysis. These results suggest that E. foeminea crude extracts most probably affect U2OS proliferation and migration ability by modulating key genes involved in the regulation of these processes and possess no cytotoxicity to human erythrocytes [24].

\section{Materials and Methods}

2.1. Plant Material Harvest. Plant aerial parts (the scale minute leaves and stems) of $E$. foeminea were collected from a female plant in July at the flowering stage from Hebron city; Lat: 31.538629 , Lon: 35.085769 . A voucher specimen was preserved for identification in the Palestine-Korea Biotechnology Center at the Palestine Polytechnic University. Morphological identification of the plant was carried out by referring to the Flora of Israel Online by Avinoam Danin (http://flora.org.il/en/plants/ephfoe/).

2.2. Crude Extract Preparation. The collected plant material was shade dried at room temperature then cut into small pieces of 1.0 to $2.0 \mathrm{~cm}$ and ground with an electric grinder into a fine powder. After sieving, the powder was separated from the residual fibers; then, one gram of the powder was mixed with $30.0 \mathrm{~mL}$ of the following analytical grade solvents, deionized water, absolute ethanol, and ethyl acetate. After $24 \mathrm{~h}$ of continuous shaking (170 rpm), the mixture was filtered, and the filtrate evaporated in a fume hood until entirely dried. The dry extract yield as a percentage of the starting powder was calculated and found to be $2 \%, 6.8 \%$, and $21.2 \%$ for ethyl acetate, ethanol, and water extracts, respectively. The dried extracts were dissolved in DMSO to make stock solutions of $150 \mathrm{mg} / \mathrm{mL}$; from these stock solutions, a series of working concentrations $(0.5,0.25,0.13,0.06$, and $0.03 \mathrm{mg} / \mathrm{mL})$ were prepared by serial dilution using complete Dulbecco's modified Eagle's medium (DMEM) cell culture media.

2.3. Cell Culture. The cell line used for this study was the U2OS human osteosarcoma cell line (kindly provided by Dr. Andreas Kakarougkas, Department of Biology, The American University in Cairo). Cells were cultured in DMEM basal media (Invitrogen, USA), supplemented with 10\% fetal bovine serum (FBS) (Invitrogen) and 5\% Pen-Strep from Invitrogen. Cells were cultured at $37^{\circ} \mathrm{C}$ and $5 \% \mathrm{CO}_{2}$ in a humidified incubator.

2.4. U2OS Doubling Time. U2OS doubling time was determined by culturing U2OS cells in a 6-well plate over a period of 6 days. Viable cell counts were made on each consecutive day using trypan blue exclusion assay. At the end of this period, a growth curve of viable cell count against time was generated and doubling time determined using equation (1) obtained from the American Type Culture Collection (ATCC) website [25]:

$$
\mathrm{DT}=T \frac{\ln 2}{\ln \left(X_{\mathrm{e}} / X_{\mathrm{b}}\right)},
$$

where DT is the doubling time. $T$ is the total time during which exponential growth occurs. $X_{\mathrm{b}}$ is the cell number at the beginning of exponential growth. $X_{\mathrm{e}}$ is the cell number at the end of the exponential growth.

2.5. MTT Cell Viability Assay. The viability of U2OS cells incubated with $E$. foeminea extracts for $24 \mathrm{~h}, 48 \mathrm{~h}$, and $72 \mathrm{~h}$ was determined using the MTT viability assay. Viable cells reduce MTT reagent (3-(4,5-dimethylthiazolyl-2)-2,5-diphenyltetrazolium bromide) (Serva, Germany) to form a purple color by mitochondrial dehydrogenase enzymes [26]. U2OS cells were incubated with $E$. foeminea extracts in a 96-well plate for $24 \mathrm{~h}, 48 \mathrm{~h}$, or $72 \mathrm{~h}$. The culture media was aspirated and $100 \mu \mathrm{L}$ of fresh media containing $20 \mu \mathrm{L}$ of MTT solution $(5.0 \mathrm{mg} / \mathrm{mL})$ was added per well and incubated for $4 \mathrm{~h}$. The culture media was discarded after incubation and replaced with $100 \mu \mathrm{L}$ of dimethyl sulfoxide (DMSO) (Sigma-Aldrich, USA) per well to solubilize the purple formazan crystals formed as a result of MTT reduction. The color change was quantified by taking absorbance readings at $570 \mathrm{~nm}$ using SPECTROstar Nano microplate reader (BMG LABTECH). The percentage of cell viability was calculated by 
expressing the absorbance of the treated wells as a percentage of the untreated wells.

2.6. Scratch Wound Healing Assay. The scratch wound healing assay was performed to test the cell migration ability of U2OS cells when incubated with E. foeminea extracts. U2OS cells were seeded at a density of $3 \times 10^{5}$ cells per well in a 6 well plate and incubated until cells were about $90 \%$ confluent. At this point, two perpendicular scratches were made in the cell monolayer with the help of a sterile $20 \mu \mathrm{L}$ pipette tip. Cells were then washed twice with 1x PBS to remove cell debris, before adding fresh complete DMEM containing extract treatments whose concentrations were adjusted to the least obtained $\mathrm{IC}_{50}$ per extract. A series of images along the scratch were taken at various points per treatment at $0 \mathrm{~h}$. Cells were then incubated at $37^{\circ} \mathrm{C} / 5 \% \mathrm{CO}_{2}$ and consecutive images taken after $6 \mathrm{~h}$ and $12 \mathrm{~h}$ for similar points along the scratch as those previously taken at $0 \mathrm{~h}$. All images were captured using the Olympus IX70 inverted microscope. Areas of the wounds were measured using ImageJ $1.51 \mathrm{j} 8$ software [27] and percentage wound closure determined using equation (2) [28]:

$$
\mathrm{WC} \%=\frac{\mathrm{WC} 0 \mathrm{~h}-\mathrm{WCX} \mathrm{h}}{\mathrm{WC} 0 \mathrm{~h}} \times 100,
$$

where $\mathrm{WC} \%$ is the percentage wound closure. WC $0 \mathrm{~h}$ is the percentage wound closure at zero hours. $\mathrm{WCX} \mathrm{h}$ is the percentage wound closure at a specified time point.

2.7. Reverse Transcription Polymerase Chain Reaction (RT$P C R)$. Analysis of differential gene expression between treated and untreated cells was performed using semiquantitative RT-PCR in which $0.5 \mu \mathrm{g}$ of total RNA was reverse transcribed using RevertAid First Strand cDNA Synthesis Kit (Thermo Scientific, USA) facilitated by random primers in a final volume of $20 \mu \mathrm{L}$, according to the manufacturer's protocol. The PCR reaction was performed using $1 \mu \mathrm{L}$ cDNA template with the MyTaq DNA Polymerase Kit (Bioline) with GAPDH serving as an endogenous control. With the exception of cycle numbers and annealing temperatures (Table S1), PCR conditions were as follows among all tested genes: $94^{\circ} \mathrm{C}$ for 3 minutes, followed by cycles of $94^{\circ} \mathrm{C}$ for 30 seconds, annealing temperature for 30 seconds, and $72^{\circ} \mathrm{C}$ for 45 seconds with a final extension carried out at $72^{\circ} \mathrm{C}$ for 7 minutes. PCR products were analyzed on $2 \%$ agarose gel, and visualization was done using the Gel Doc EZ System (Bio-Rad, USA). Working solution concentrations for all primers used were set to $10 \mathrm{pmol}$ with the exception of GAPDH primers whose working concentration was set to 5 pmol.

2.8. In Silico Analysis. U2OS microarray datasets in which U2OS cells were treated with either doxorubicin or nutlin-3 [29] were retrieved from the Gene Expression Omnibus (GEO) database. Microarray datasets were processed in R using Bioconductor package annaffy (http://www.bioconductor.org/ packages/release/bioc/html/annaffy.html) [30]. The analysis was made for differentially expressed genes with both $P$ value and fold change cutoffs, respectively, set to 0.05 and 2. Acces- sion numbers and descriptions of the various datasets used are shown in Table S2.

2.9. Hemolysis Assay. After obtaining approval from the Institutional Review Board (IRB) of the American University in Cairo, blood samples from healthy volunteers were collected, after informed consent was obtained, by a physician at the university clinic. $2.0 \mathrm{~mL}$ of fresh blood was acquired per experiment. Human erythrocytes mixed with EDTA (ethylenediaminetetraacetic acid) as an anticoagulant were centrifuged for 5 minutes at $1000 \mathrm{~g}$ at $4^{\circ} \mathrm{C}$, then washed twice in PBS for complete removal of serum. Red blood cells (RBCs) were finally diluted to $2 \%$ concentration in PBS, and $60 \mu \mathrm{L}$ of this solution was added to each well in a flatbottomed 96 -well plate. $60 \mu \mathrm{L}$ of either ethanol or water extract was added per well such that the final erythrocyte concentration was $1 \%$. Concentrations close to $\mathrm{IC}_{75}, \mathrm{IC}_{50}$, and $\mathrm{IC}_{25}$ were tested per extract; these included $260.4 \mu \mathrm{g} / \mathrm{mL}$, $97.5 \mu \mathrm{g} / \mathrm{mL}$, and $36.5 \mu \mathrm{g} / \mathrm{mL}$ for the ethanol extract along with $127.7 \mu \mathrm{g} / \mathrm{mL}, 30.8 \mu \mathrm{g} / \mathrm{mL}$, and $7.4 \mu \mathrm{g} / \mathrm{mL}$ for the water extract. Plates were incubated for $1 \mathrm{~h}$ at $37^{\circ} \mathrm{C}$. Untreated RBCs and deionized water were, respectively, used as controls for $0 \%$ and $100 \%$ hemolysis. Plates were then centrifuged at $3000 \mathrm{~g}$ for 10 minutes at $4^{\circ} \mathrm{C}$, after which $100 \mu \mathrm{L}$ of supernatant was transferred to a clean flat-bottomed plate. The supernatant's absorbance was measured at $570 \mathrm{~nm}$ and the percentage of hemolysis determined using equation (3) [31]:

$$
\operatorname{Hemolysis}(\%)=\frac{\left(A_{\max }-A_{\mathrm{t}}\right)}{\left(A_{\max }-A_{\min }\right)} \times 100
$$

where $A_{\text {max }}, A_{\text {min }}$, and $A_{\mathrm{t}}$ represent the absorbance values for untreated, completely hemolyzed, and tested RBCs, respectively.

2.10. Statistical Analysis. All data generated were presented as the mean \pm standard deviation of three independent experiments unless otherwise specified and were analyzed using GraphPad Prism 6.01 software [32]. Multiple comparison analyses were performed using either two-way or one-way ANOVA (analysis of variance) followed by Dunnett's post multiple comparisons test. Pairwise analyses were, on the other hand, performed using GraphPad Prism's multiple $t$ -test analysis with multiple comparisons corrected for using the Holm-Sidak method.

Dose-response curves and $\mathrm{IC}_{50}$ values were generated in GraphPad Prism 6.01 using (log (inhibitor) vs.normalized response - variable slope). ImageJ software was used to analyze the intensities of the PCR bands; these were normalized to the endogenous control (GAPDH) and used to calculate relative gene expression presented as fold change relative to untreated cells. $P$ values less than 0.05 were considered significant $(* P<0.05, * * P<0.01$, and $* * * P<0.001)$.

\section{Results}

3.1. U2OS Growth Characteristics. U2OS cells used in this study were cultured over a period of six days, and the number of viable cells per $\mathrm{mL}$ was determined for each consecutive 

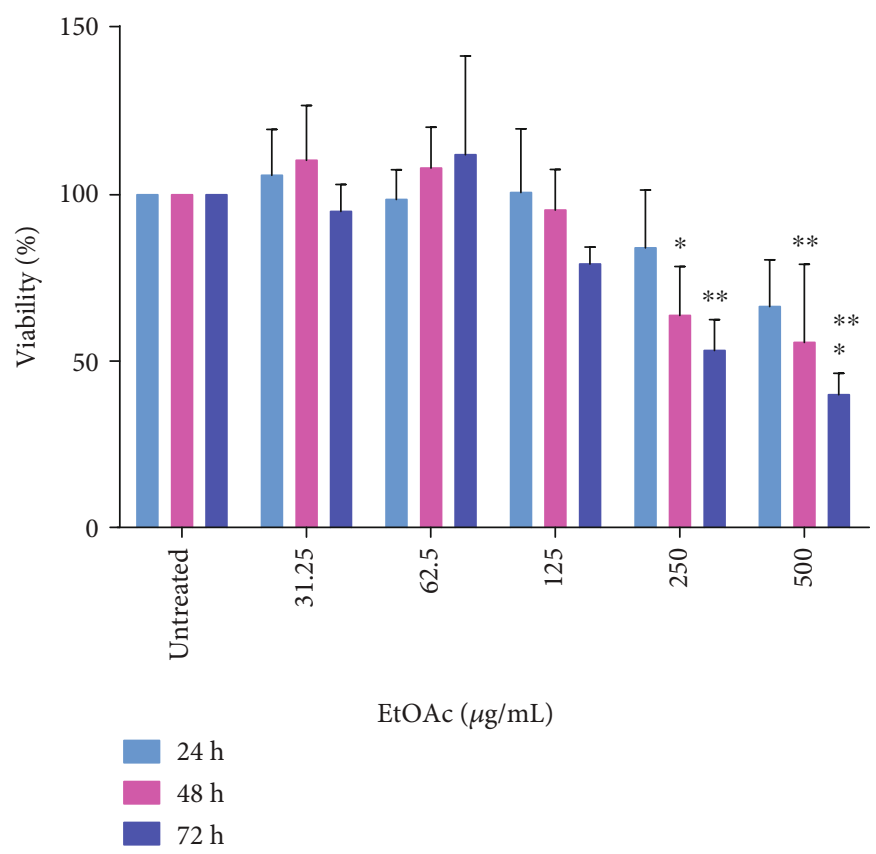

EtOAc $(\mu \mathrm{g} / \mathrm{mL})$

$48 \mathrm{~h}$

$72 \mathrm{~h}$

(a)

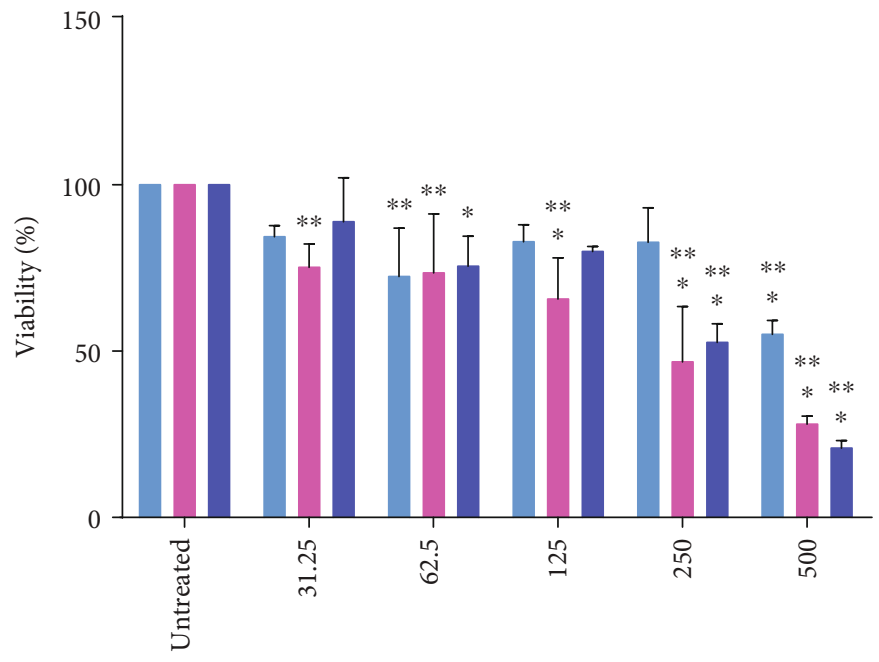

$\mathrm{EtOH}(\mu \mathrm{g} / \mathrm{mL})$

$24 \mathrm{~h}$

$48 \mathrm{~h}$

$72 \mathrm{~h}$

(b)

Figure 1: Continued. 


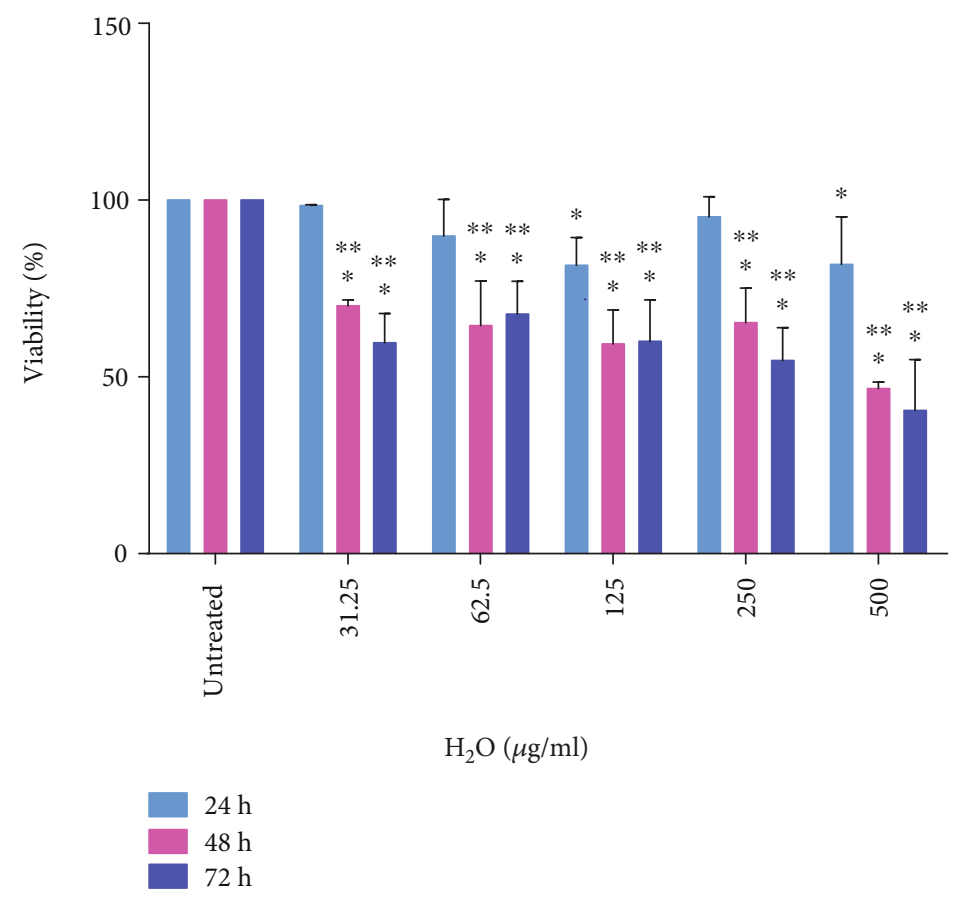

(c)

FIGURE 1: Effect of E. foeminea (a) ethyl acetate, (b) ethanol, and (c) water extracts on U2OS cell viability; all extracts generally showed a reduction in percentage cell viability that was both dose- and time-dependent. $* * * P \leq 0.001, * * P \leq 0.01$, and $* P \leq 0.05 ; n=3$.

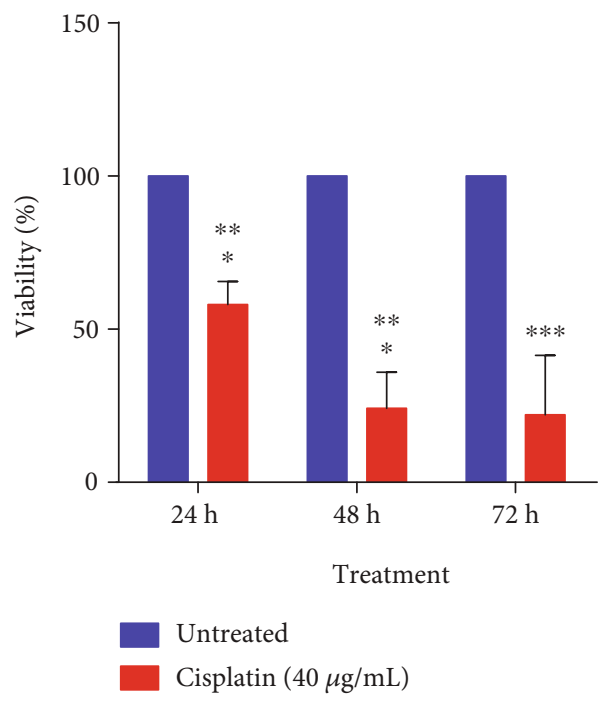

(a)

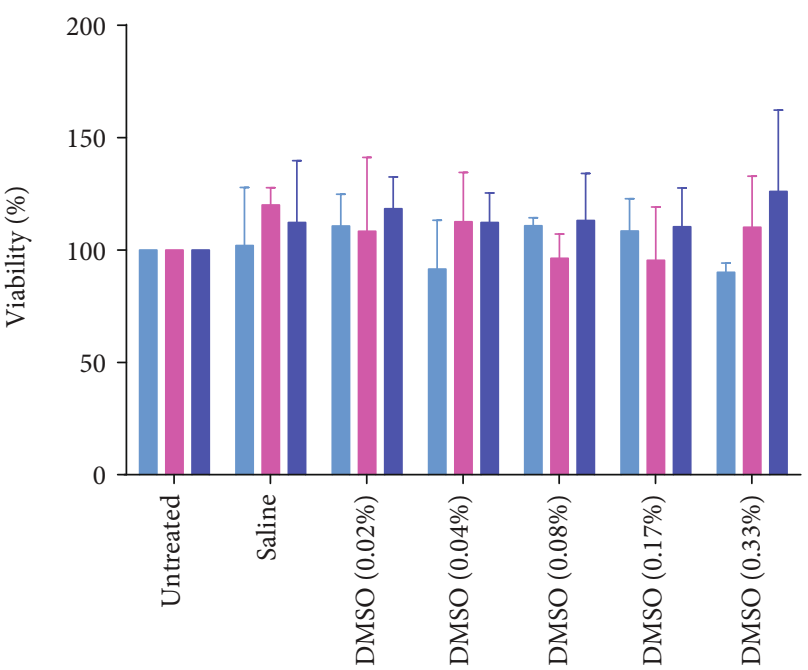

Treatment

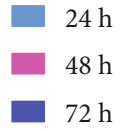

(b)

FIGURE 2: Effect of cisplatin and DMSO on U2OS viability. (a) The positive control, cisplatin ( $40 \mu \mathrm{g} / \mathrm{mL})$, significantly reduced U2OS viability at all examined time points. (b) DMSO, in which E. foeminea extracts were dissolved, appeared to have no significant effect on U2OS cell viability. $* * * P \leq 0.001, * * P \leq 0.01$, and $* P \leq 0.05 ; n=3$.

day. The obtained growth curve exhibited a sigmoidal pattern with lag, exponential, and stationary phases during which cells exhibited slow, exponential, and stationary growth rates, respectively. The lag phase lasted 2 days, after which the cells grew exponentially until the fourth day. The cell growth rate then decelerated between the 4 th and 5 th days and finally 


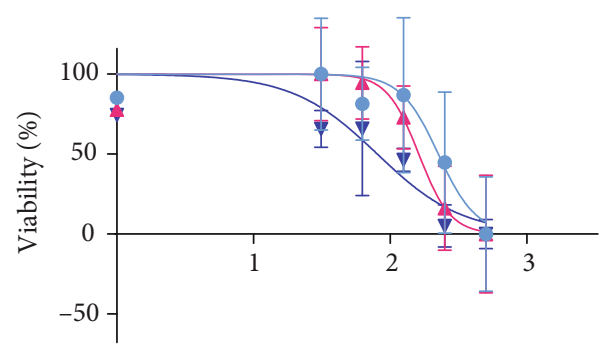

$\log [\mathrm{EtOAc}](\mu \mathrm{g} / \mathrm{mL})$

$$
\begin{array}{r}
-24 \mathrm{~h} \\
-\quad 48 \mathrm{~h} \\
-\quad 72 \mathrm{~h}
\end{array}
$$

(a)

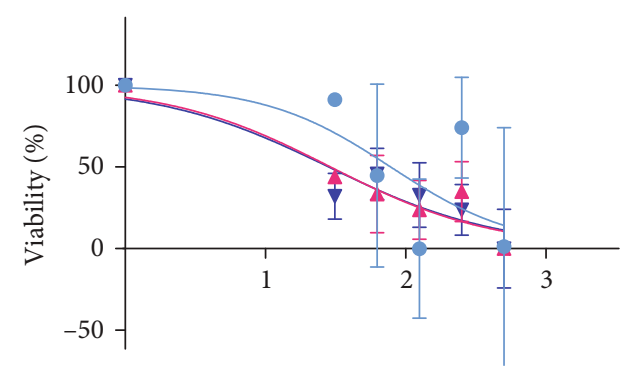

$\log \left[\mathrm{H}_{2} \mathrm{O}\right](\mu \mathrm{g} / \mathrm{mL})$

$-24 \mathrm{~h}$
$-\quad 48 \mathrm{~h}$
$\rightarrow-72 \mathrm{~h}$

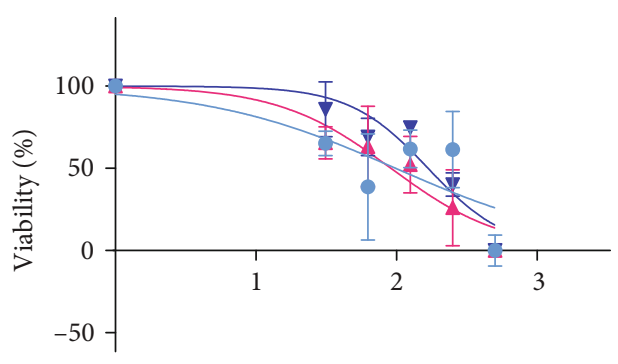

$\log [\mathrm{EtOH}](\mu \mathrm{g} / \mathrm{mL})$

$-24 \mathrm{~h}$

$-48 \mathrm{~h}$

$\rightarrow 72 \mathrm{~h}$

(b)

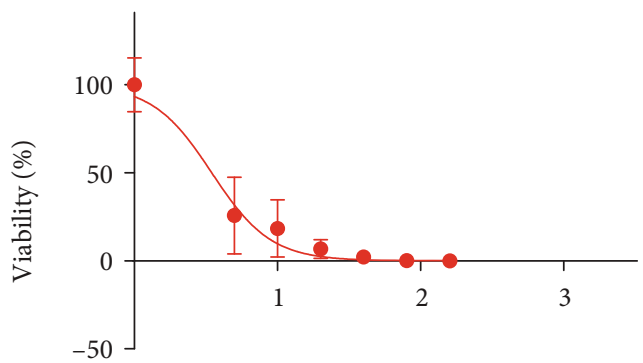

Log [cisplatin] $(\mu \mathrm{g} / \mathrm{mL})$

$-72 \mathrm{~h}$

(d)

FIGURE 3: U2OS dose-response curves. E. foeminea (a) ethyl acetate, (b) ethanol, and (c) water extracts. (d) Dose-response curve for cisplatin

\begin{tabular}{|c|c|c|c|c|}
\hline Treatment & Time $(\mathrm{h})$ & $\mathrm{IC}_{50} \pm$ Std.Error $(\mu \mathrm{g} / \mathrm{mL})$ & Hill coefficient \pm Std.Error & Sy.x* \\
\hline \multirow{3}{*}{ EtOAc } & 24 & $224.6 \pm 1.234$ & $3.143 \pm 1.941$ & 31.92 \\
\hline & 48 & $161.6 \pm 1.164$ & $3.738 \pm 1.639$ & 23.80 \\
\hline & 72 & $80.4 \pm 1.221$ & $1.401 \pm 0.402$ & 19.43 \\
\hline \multirow{3}{*}{$\mathrm{EtOH}$} & 24 & $98.45 \pm 1.541$ & $0.645 \pm 0.275$ & 24.5 \\
\hline & 48 & $91.21 \pm 1.220$ & $1.082 \pm 0.267$ & 16.49 \\
\hline & 72 & $167.4 \pm 1.139$ & $1.554 \pm 0.307$ & 13.61 \\
\hline \multirow{3}{*}{$\mathrm{H}_{2} \mathrm{O}$} & 24 & $78.01 \pm 1.894$ & $0.967 \pm 0.723$ & 47.7 \\
\hline & 48 & $29.12 \pm 1.434$ & $0.751 \pm 0.205$ & 15.96 \\
\hline & 72 & $28.23 \pm 1.522$ & $0.716 \pm 0.217$ & 18.08 \\
\hline Cisplatin & 72 & $3.473 \pm 1.106$ & $2.108 \pm 0.340$ & 12.58 \\
\hline
\end{tabular}
(positive control); percentage viabilities were normalized to a scale running from $0 \%$ to $100 \%$.

TABLE 1: Summary of $\mathrm{IC}_{50}$ and Hill coefficient values obtained for E. foeminea extract treatments.

*Standard deviation of the residuals in units of the $y$-axis of the dose-response curves.

leveled off on the 6th day. The number of cells increased by about sevenfold during the entire growth period with a calculated doubling time of 1.2 days (Figure S1).

3.2. MTT Assay. MTT assay was utilized to determine the effect of the various $E$. foeminea extracts on $\mathrm{U} 2 \mathrm{OS}$ cell viability over a series of concentrations ranging from $31.25 \mu \mathrm{g} / \mathrm{mL}$ to $1000 \mu \mathrm{g} / \mathrm{mL}$ at $24 \mathrm{~h}, 48 \mathrm{~h}$, and $72 \mathrm{~h}$ time points. Generally, when treated with $E$. foeminea ethyl acetate extract, U2OS cells showed a reduction in percentage cell viability that was both dose- and time-dependent (Figure 1(a)). Percentage viability reduced with increasing extract concentration; significant 


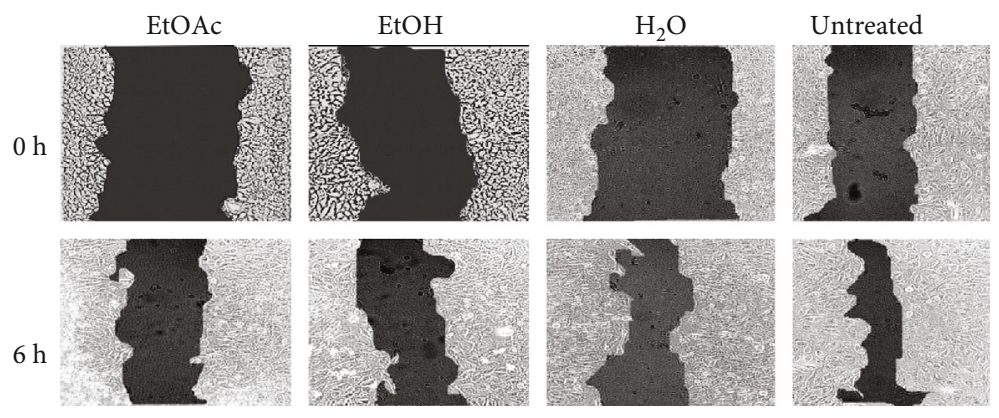

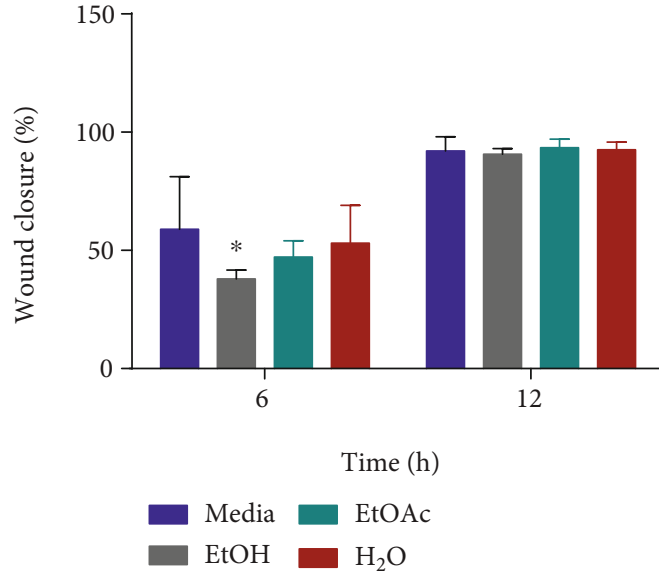

(b)

FIgURE 4: Effect of E. foeminea on U2OS cell migration. (a) Wound healing assay representative images at the $6 \mathrm{~h}$ time point. (b) Percentage wound closure measured at both $6 \mathrm{~h}$ and $12 \mathrm{~h}$ time points. All extracts reduced U2OS percentage wound closure at the $6 \mathrm{~h}$ time point with only the ethanol extract showing statistically significant results; $* P=0.013, n=3$.

reductions in viability were observed at concentrations of 250 and $500 \mu \mathrm{g} / \mathrm{mL}$ for both the $48 \mathrm{~h}$ and $72 \mathrm{~h}$ time points when compared to untreated cells. The reduction in cell viability at the $24 \mathrm{~h}$ time point showed no statistical significance.

All concentrations below $250 \mu \mathrm{g} / \mathrm{mL}$ showed no significant decrease in viability. Furthermore, percentage viability declined with increasing incubation time for individual extract concentrations. The most significant reduction in cell viability was observed at the extract concentration of $500 \mu \mathrm{g} / \mathrm{mL}$ for the $72 \mathrm{~h}$ time point $(* * * P<0.001)$ while the least significant reduction in cell viability was observed at $250 \mu \mathrm{g} / \mathrm{mL}$ for the $48 \mathrm{~h}$ time point.

The E. foeminea ethanol extract showed a similar trend to the ethyl acetate extract with regard to its effect on U2OS cell viability (Figure $1(\mathrm{~b})$ ). The $500 \mu \mathrm{g} / \mathrm{mL}$ concentration significantly decreased the viability of U2OS cells at all time points with $P$ values of less than 0.0001 . The ethanol extract at $250 \mu \mathrm{g} / \mathrm{mL}$ significantly reduced the viability of U2OS cells at only $48 \mathrm{~h}$ and $72 \mathrm{~h}$ time points $(* * * P<0.001)$. Other significant decreases in viability were observed at extract concentrations of $125 \mu \mathrm{g} / \mathrm{mL}$ for both $48 \mathrm{~h}$ and $72 \mathrm{~h}$ time points ( $P$ values 0.001 and 0.02 , respectively). In addition, the extract concentration at $62.5 \mu \mathrm{g} / \mathrm{mL}$ also showed significant decreases in viability at $24 \mathrm{~h}, 48 \mathrm{~h}$, and $72 \mathrm{~h}$ time points ( $P$ values $0.0026,0.0020$, and 0.0065 , respectively). The least significant reduction in viability was observed for the $31.25 \mu \mathrm{g} / \mathrm{mL}$ ethanol extract concentration at only the $48 \mathrm{~h}$ time point ( $P$ value 0.002$)$. The greatest decline in $\mathrm{U} 2 \mathrm{OS}$ cell viability was observed for the ethanol extract with a concentration of $500 \mu \mathrm{g} / \mathrm{mL}$ at the $72 \mathrm{~h}$ time point.

U2OS cells treated with $E$. foeminea water extract similarly showed a decline in viability in a manner that was both dose- and time-dependent (Figure 1(c)). All concentrations of the water extract showed significant decreases in viability at all time points except the extracts at 250, 62.5, and $31.25 \mu \mathrm{g} / \mathrm{mL}$ for the $24 \mathrm{~h}$ time point. Extract concentrations that showed the highest significant decrease in percentage viability $(* * * P<0.001)$ included $62.5,125,250$, and $500 \mu \mathrm{g} / \mathrm{mL}$ for both the $48 \mathrm{~h}$ and $72 \mathrm{~h}$ time points.

Cisplatin $(40 \mu \mathrm{g} / \mathrm{mL})$, used as a positive control, showed significant decreases in $\mathrm{U} 2 \mathrm{OS}$ viability at all time points tested (Figure 2(a)). DMSO, in which extracts were dissolved generally, had no significant effect on U2OS cell viability (Figure 2(b)) at all concentrations for all time points. $P$ values obtained for all extract treatments are summarized in Table S3.

3.3. $I C_{50}$. Results obtained from the MTT assay were used to determine the $\mathrm{IC}_{50}$ values for all extracts at all time points using nonlinear regression analysis. Dose-response curves (Figures 3(a)-3(c)) for E. foeminea ethyl acetate, ethanol, and water extracts were plotted for $24 \mathrm{~h}, 48 \mathrm{~h}$, and $72 \mathrm{~h}$ time points and used to generate $\mathrm{IC}_{50}$ values per extract per time point (Table 1). The least $\mathrm{IC}_{50}$ values obtained per extract were $80.4 \mu \mathrm{g} / \mathrm{mL}$ at $72 \mathrm{~h}, 91.2 \mu \mathrm{g} / \mathrm{mL}$ at $48 \mathrm{~h}$, and $28.23 \mu \mathrm{g} / \mathrm{mL}$ at $72 \mathrm{~h}$, respectively, for ethyl acetate, ethanol, and water extracts.

Concentrations close to the least obtained $\mathrm{IC}_{50}$ per extract were used for downstream analyses; these concentrations included $80.353 \mu \mathrm{g} / \mathrm{mL}, 97.499 \mu \mathrm{g} / \mathrm{mL}$, and $30.761 \mu \mathrm{g} / \mathrm{mL}$ for ethyl acetate, ethanol, and water extracts. The obtained extract $\mathrm{IC}_{50}$ values were compared to the $\mathrm{IC}_{50}$ of cisplatin when incubated with U2OS cells for $72 \mathrm{~h}$. The effect of varying concentrations of cisplatin ranging from 5 to $160 \mu \mathrm{g} / \mathrm{mL}$ on the viability of U2OS cells was studied; the generated doseresponse curve (Figure 3(d)) was utilized to calculate the $\mathrm{IC}_{50}$ of cisplatin at the $72 \mathrm{~h}$ time point (Table 1). Cisplatin $\operatorname{IC}_{50}(3.473 \mu \mathrm{g} / \mathrm{mL})$ was over 18 times lower than that of all E. foeminea extracts.

Obtained Hill-slope coefficients for cisplatin (at $72 \mathrm{~h}$ ), ethyl acetate (at $72 \mathrm{~h}$ ), ethanol (at $48 \mathrm{~h}$ ), and water (at $72 \mathrm{~h}$ ) extracts were compared; apart from the water extract, all other treatments possessed Hill-slope coefficients greater than 1 , with the highest ratio observed for cisplatin. The least 


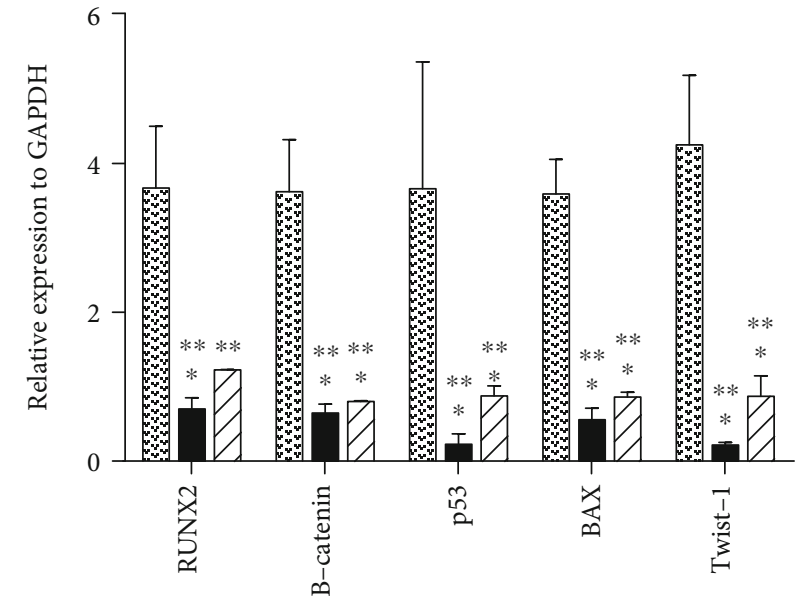

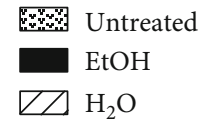

(a)

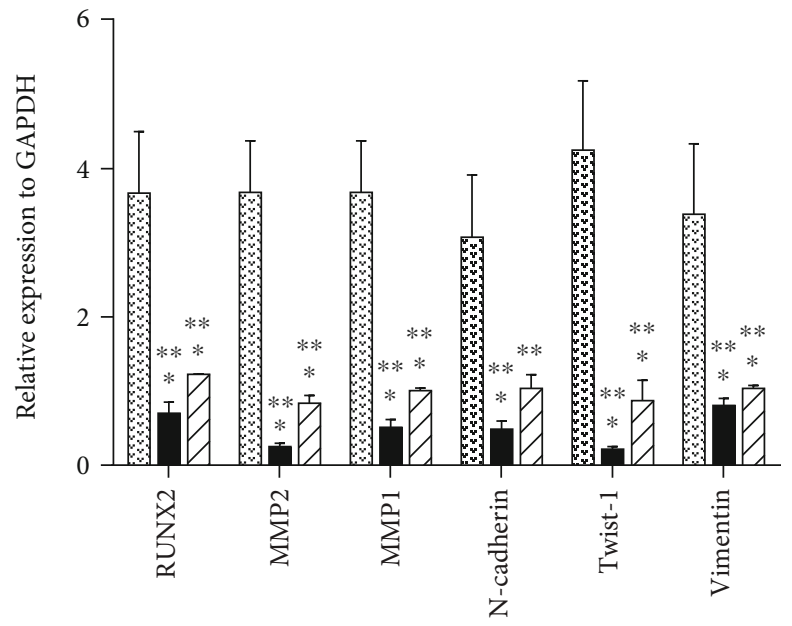

Untreated
EtOH
$\square \mathrm{H}_{2} \mathrm{O}$

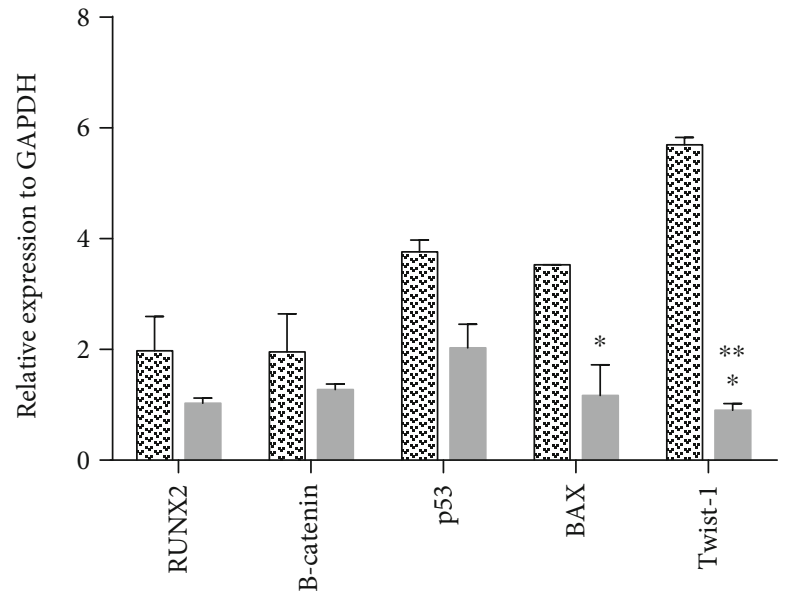

Untreated EtOAc (b)

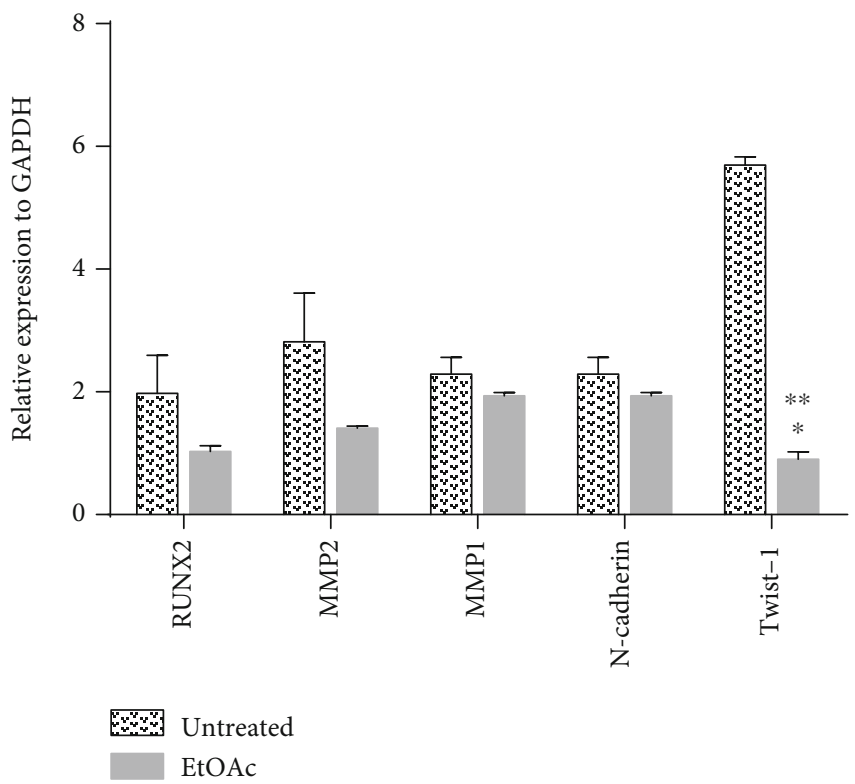

(d)

Figure 5: RT-PCR ImageJ analysis. (a, b) mRNA steady-state levels for genes (RUNX2, B-catenin, p53, BAX, and Twist-1) involved in cell proliferation and apoptosis. (c, d) mRNA steady-state levels for genes (RUNX2, MMP2, MMP1, N-cadherin, Twist-1, and vimentin) involved in cell migration. U2OS cells were treated with either ethanol, water, or ethyl acetate extracts adjusted to the least $\mathrm{IC}_{50}$ value obtained per extract at respective time points. $* * * P \leq 0.001, * * P \leq 0.01$, and $* P \leq 0.05 ; n=3$.

obtained $\mathrm{IC}_{50}$ per treatment also possessed relatively low Sy.x (standard deviation of the residuals) values, indicating that the goodness of fit for the data collected at these time points was acceptable (Table 1 ).

3.4. Cell Morphology. The effect of E. foeminea extracts on U2OS cell morphology was studied. Ethyl acetate, ethanol, and water extract treatments, respectively, adjusted to concentrations close to the least obtained $\mathrm{IC}_{50}$ value per treatment. $E$. foeminea extracts showed no marked effect on cell morphology when compared to untreated cells at all time points. Generally, U2OS cells used for this study grew as a monolayer adherent to the surface of the culture flasks. The cells mostly possessed an elliptical shape in which they appeared wider at the center but tapered on either end (Figure S2).

3.5. Wound Healing Assay. The wound healing assay was performed, and the percentage wound closure was determined for both $6 \mathrm{~h}$ and $12 \mathrm{~h}$ time points. At the $6 \mathrm{~h}$ time point, results of percentage wound closure showed that untreated cells had the highest wound closure, respectively, followed by cells treated with water, ethyl acetate, and ethanol extracts. At this time point, percentage wound closure for all cells treated with extract was lower than that of untreated cells, 
TABLE 2: mRNA steady-state gene expression for markers involved in cell proliferation, apoptosis, and migration shown as fold change relative to that observed in untreated cells.

\begin{tabular}{lcccccc}
\hline & \multicolumn{2}{c}{ EtOH } & \multicolumn{2}{c}{$\mathrm{H}_{2} \mathrm{O}$} & \multicolumn{2}{c}{ EtOAc } \\
Gene & $\begin{array}{c}\text { Fold } \\
\text { change }\end{array}$ & $P$ value & Fold & $P$ value & Fold & $P$ change \\
& & & & change & \\
\hline Twist-1 & -19.360 & $<0.001$ & -4.870 & $<0.001$ & -6.33 & $<0.001$ \\
p53 & -16.038 & $<0.001$ & -4.166 & $<0.001$ & -1.857 & 0.035 \\
MMP2 & -14.657 & $<0.001$ & -4.383 & $<0.001$ & -1.994 & 0.131 \\
MMP1 & -7.177 & $<0.001$ & -3.658 & $<0.001$ & -1.181 & 0.220 \\
BAX & -6.471 & $<0.001$ & -4.172 & $<0.001$ & -3.011 & 0.027 \\
N- & -6.329 & $<0.001$ & -2.966 & 0.001 & -1.181 & 0.220 \\
cadherin & -629 & & & & & \\
B- & -5.601 & $<0.001$ & -4.503 & $<0.001$ & -1.533 & 0.299 \\
catenin & -601 & & & & & \\
RUNX2 & -5.211 & $<0.001$ & -2.993 & 0.001 & -1.918 & 0.166 \\
Vimentin & -4.189 & $<0.001$ & -3.265 & 0.001 & - & - \\
\hline
\end{tabular}

although a significant decline in percentage wound closure was observed for only cells treated with ethanol extract $(P$ value $=0.013)$. There was no significant difference in percentage wound closure at the $12 \mathrm{~h}$ time point when treated cells were compared to untreated ones (Figure 4).

3.6. RT-PCR. mRNA expression for various genes involved in either cell proliferation and apoptosis or cell migration was assessed in both treated and untreated cells using RT-PCR (Figure 5) (Figure S3). mRNA steady-state levels for several genes involved in either cell proliferation and apoptosis (RUNX2, B-catenin, p53, BAX, and Twist-1) (Figures 5(a) and 5(b)) or cell migration (RUNX2, MMP2, MMP1, Ncadherin, Twist-1, and vimentin) (Figures 5(c) and 5(d)) were assessed for U2OS cells treated with either ethanol, water, or ethyl acetate extracts adjusted to the least $\mathrm{IC}_{50}$ value obtained per extract. The expression of all genes tested was significantly decreased by varying folds in both the ethanol and water extracts. The ethanol extract reduced the expression of the tested genes much more than the water extract. The genes whose expression was reduced the most by the ethanol extract included Twist-1, p53, and MMP2 while B-catenin, RUNX2, and vimentin were the least affected. A similar trend was observed for the ethyl acetate extract in which all tested genes were downregulated. However, apart from Twist-1, the downregulation of all other tested genes by the ethyl acetate extract showed no statistical significance when compared to the untreated cells (Table 2).

3.7. Comparison of U2OS Gene Expression when Treated with Either E. foeminea Extracts, Doxorubicin, Or Nutlin-3. U2OS gene expression datasets for both doxorubicin and nutlin-3 treatments were obtained from the GEO database and analyzed for differentially expressed genes at a $P$ value cutoff of 0.05 and fold cutoff of 2; the comparison was made to U2OS gene expression when treated with $E$. foeminea extracts. Of the 9 genes examined in this study, 5 (BAX, MMP1, MMP2, TP53, and vimentin) were exclusively down- regulated by $E$. foeminea crude extracts while 2 (B-catenin and $\mathrm{N}$-cadherin) were downregulated in both E. foeminea and doxorubicin treatments only. On the other hand, only 1 (Twist-1) gene was downregulated solely by both $E$. foeminea and Nutlin-3 while all the three treatments were shown to downregulate 1 (RUNX2) gene. Although E. foeminea showed no upregulation of any of the tested genes, BAX was upregulated by both doxorubicin and nutlin-3 treatments while Twist- 1 was exclusively upregulated by doxorubicin (Figure 6, Table 3). The entire lists of all genes analyzed for both doxorubicin and nutlin-3 treatments are, respectively, presented in Supplementary Files 1 and 2. Both $\operatorname{logFC}$ (log of fold change) and $P$ values for each gene are reported.

3.8. Hemolysis Assay. Hemolytic activity for both ethanol and water extracts was tested on human erythrocytes using the hemolytic assay. Since the ethyl acetate extract gave the least biological activity, it was excluded from the hemolysis test. The hemolytic assay measures the amount of hemoglobin liberated from lysed RBCs by spectrophotometric means [33]. Hemolytic activities for both ethanol and water extracts adjusted to concentrations close to $\mathrm{IC}_{75}, \mathrm{IC}_{50}$, and $\mathrm{IC}_{25}$ were compared to both untreated RBCs (no hemolysis) and RBCs treated with deionized water (100\% hemolysis). All tested concentrations for both extracts showed negligible hemolytic activity, comparable to the untreated RBCs. The ethanol extract generally showed lower hemolytic activity than the water extract at all tested concentrations; however, this difference showed no statistical significance (Figure 7).

\section{Discussion}

The obtained growth curve for U2OS cells used in this study showed definite lag, exponential, and stationary phases during which cells, respectively, went through a period of slow growth, followed by a period of exponential growth and finally transitioned into another slow growth phase as cells reached confluency [34] (Figure S1). U2OS cell growth with respect to this study followed a characteristic sigmoid growth pattern with a doubling time of 1.2 days. This was similar to the doubling time of 1.25 days previously reported by Rey and colleagues [35]. However, U2OS doubling times as high as 2.75 days have been reported [36].

The effect of $E$. foeminea ethyl acetate, ethanol, and water extracts on U2OS cell viability was determined using MTT assay, which involves assessing the metabolic activity of cells by quantifying the intensity of purple formazan crystals formed after viable cells reduce the yellow MTT reagent [37]. E. foeminea ethyl acetate, ethanol, and water extracts each significantly decreased U2OS percentage cell viability in a manner dependent on both concentration and time (Figures 1(a)-1(c)); generally, longer incubation times and higher extract concentrations favored the reduction of U2OS percentage cell viability. These results are in agreement with previous findings where both $E$. foeminea ethanol and fruit juice extracts significantly decreased the viability of MDA MB 231 breast cancer, HCT 116 colorectal cancer, and normal HaCat keratinocyte cells [20]. Our results however contradicted with those of Ben-Arye and colleagues in which 


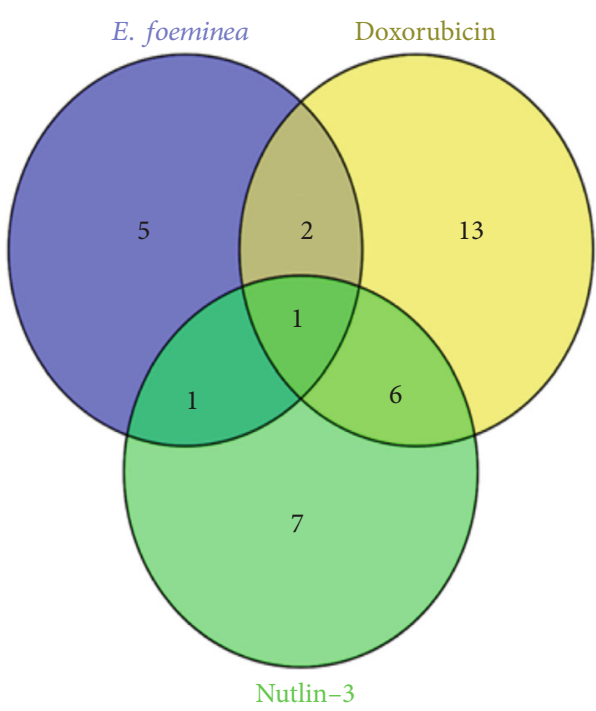

(a)

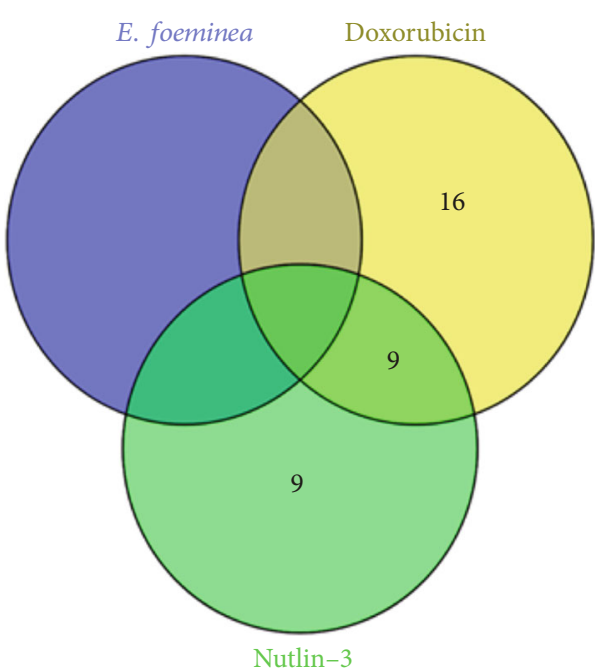

(b)

FIGURE 6: Venn diagrams comparing gene expression in U2OS cells treated with either E. foeminea, doxorubicin, or nutlin-3. (a) represents the number of downregulated genes while (b) represents the number of upregulated genes per treatment.

TABLE 3: Comparison of U2OS gene expression when treated with either E. foeminea, doxorubicin, or nutlin-3.

\begin{tabular}{|c|c|c|c|c|}
\hline \multirow{2}{*}{$\begin{array}{l}\text { Treatment } \\
\text { E. foemineandoxorubicinnnutlin-3 }\end{array}$} & \multicolumn{2}{|c|}{ Downregulated genes } & \multicolumn{2}{|c|}{ Upregulated genes } \\
\hline & RUNX2 & - & - & - \\
\hline E. foemineandoxorubicin & B-catenin & $\mathrm{N}$-cadherin & - & - \\
\hline E. foemineannutlin-3 & Twist-1 & - & - & - \\
\hline \multirow{3}{*}{ E. foeminea } & MMP2 & BAX & - & - \\
\hline & TP53 & MMP1 & - & - \\
\hline & Vimentin & - & - & - \\
\hline \multirow{5}{*}{ Doxorubicinnnutlin-3 } & DCHS2 & BIRC5 & FAT3 & BAX \\
\hline & FAT4 & $\mathrm{CDH} 12$ & PIDD1 & $\mathrm{CDH} 10$ \\
\hline & $\mathrm{SOX} 2$ & $\mathrm{CDH} 18$ & TP53I11 & $\mathrm{CDH} 22$ \\
\hline & - & - & TP53I3 & CDIP1 \\
\hline & - & - & TP53INP1 & \\
\hline \multirow{8}{*}{ Doxorubicin } & XIAP & CBY1 & LOC100653137///CDH23 & $\mathrm{CDH} 9$ \\
\hline & CPED1 & $\mathrm{CDH} 4$ & MIR6513///TMBIM1 & CDHR1 \\
\hline & CTNNA1 & CELSR3 & TMBIM6 & CDHR3 \\
\hline & CTNND2 & CPED1 & TP53AIP1 & CELSR1 \\
\hline & FAT1 & TP53BP1 & TP53I13 & CELSR2 \\
\hline & FAT3 & JMY & TP53INP2 & CTNNB1 \\
\hline & TMBIM4 & - & Twist-1 & DACT1 \\
\hline & TMX2-CTNND1///CTNND1 & - & TWIST2 & DACT3 \\
\hline \multirow{5}{*}{ Nutlin-3 } & CELSR2 & $\mathrm{CDH} 24$ & CBY1 & JMY \\
\hline & DACT1 & CDH6 & CDH11 & LINC-PINT \\
\hline & DCHS1 & CDHR2 & $\mathrm{CDH} 13$ & TWISTNB \\
\hline & LOC100653137///CDH23 & - & CDH15 & XIAP \\
\hline & - & - & $\mathrm{CDH} 16$ & - \\
\hline
\end{tabular}




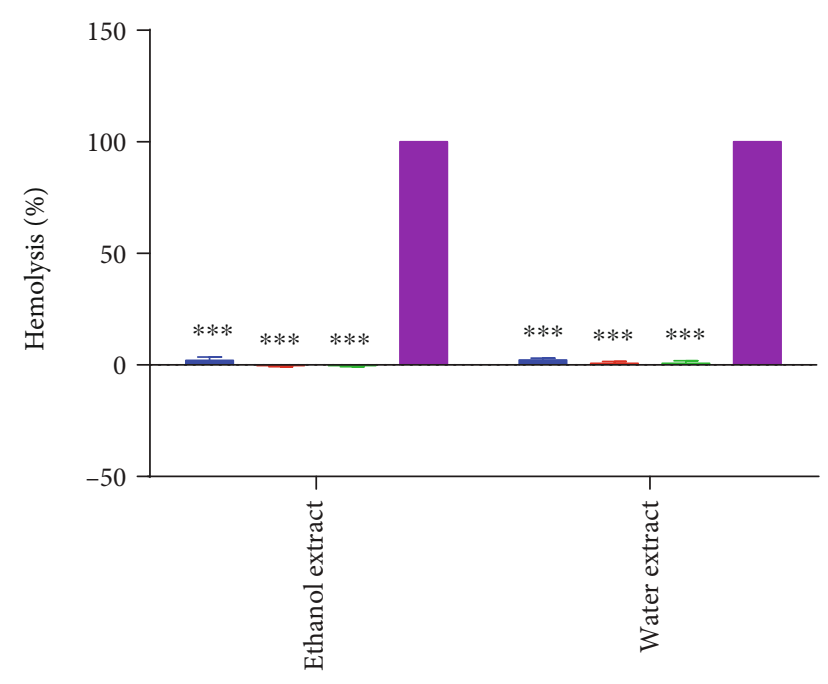

Extracts

Figure 7: Hemolytic activity of E. foeminea ethanol and water extracts. Deionized water (purple) represents $100 \%$ hemolysis. Three concentrations for each extract were tested: $260.4 \mu \mathrm{g} / \mathrm{mL}$ (blue), $97.5 \mu \mathrm{g} / \mathrm{mL}$ (red), and $36.5 \mu \mathrm{g} / \mathrm{mL}$ (green) for the ethanol extract along with $127.7 \mu \mathrm{g} / \mathrm{mL}$ (blue), $30.8 \mu \mathrm{g} / \mathrm{mL}$ (red), and $7.4 \mu \mathrm{g} / \mathrm{mL}$ (green) for the water extract. $* * * P \leq 0.001, n=3$.

they reported that $E$. foeminea boiled water extract showed no significant effect on the percentage viability of both MDA MB 231 and SKBR3 breast cancer cells [19]. This disparity can be attributed to the difference in extraction methods employed per study; it has been shown that different extraction procedures have varying influences on the physical, chemical, and biological properties of the final extract [38]. DMSO, in which our extracts were dissolved, showed no significant effect on U2OS cell viability (Figure 2(b)), indicating that the working concentrations of DMSO present in the prepared extracts did not significantly interfere with $\mathrm{U} 2 \mathrm{OS}$ viability.

Based on results obtained from the MTT assay, doseresponse curves were plotted for all $E$. foeminea extracts tested at $24 \mathrm{~h}, 48 \mathrm{~h}$, and $72 \mathrm{~h}$ time points (Figures $3(\mathrm{a})-3(\mathrm{c})$ ) and used to determine $\mathrm{IC}_{50}$ values per extract per time point (Table 1). When $\mathrm{IC}_{50}$ values per extract were compared at each time point, results showed that the ethyl acetate extract $\mathrm{IC}_{50}$ decreased at each consecutive time point with the $24 \mathrm{~h}$ time point as a reference. On the other hand, $\mathrm{IC}_{50}$ values of both ethyl acetate and water extracts were at their lowest at the $72 \mathrm{~h}$ time point but slightly higher at the $48 \mathrm{~h}$ time point. These results suggest that the potency of E. foeminea extracts is influenced by the incubation time. While E. foeminea ethanol extract was most potent at the $48 \mathrm{~h}$ time point, both the ethyl acetate and water extracts showed the greatest potency at the $72 \mathrm{~h}$ time point. For both the ethanol and water extracts, a slight reduction in cytotoxicity is observed after $72 \mathrm{~h}$ of incubating the U2OS cells with the respective extract. This result could be related to the doubling time of the U2OS cells. After $72 \mathrm{~h}$, the surviving cells would have tripled, producing new "unaffected" cells. All E. foeminea $\mathrm{IC}_{50}$ values obtained in this study were relatively lower than those previously reported [20]; these were about $570 \mu \mathrm{g} / \mathrm{mL}$ and $750 \mu \mathrm{g} / \mathrm{mL}$, respectively, for MDA-MB-231 and HaCat cells treated with $E$. foeminea ethanol extract for $48 \mathrm{~h}$. This suggests that in addition to the extraction method employed, the potency of $E$. foeminea probably varies from one cell line to another. A comparison of the least obtained $\mathrm{IC}_{50}$ values per extract shows that the least $\mathrm{IC}_{50}$ values were observed in the most polar extraction solvent which was water than in the moderately polar ethanol and ethyl acetate solvents [39]. It is likely that the more polar fractions of E. foeminea contain higher amounts of the active inhibitory compound(s). Cisplatin, a drug commercially used in osteosarcoma treatment [40], had a much lower $\mathrm{IC}_{50}$ than all $\mathrm{IC}_{50}$ values obtained for all E. foeminea extracts at all time points (Figure 3(d), Table 1). The high E. foeminea extract $\mathrm{IC}_{50}$ values relative to cisplatin can be partly explained by the fact that the E. foeminea extracts were tested in their crude form without purifying the active compound(s) [41].

Hill coefficients for all extract treatments were generally above 1, with the exception of the water extract (Table 1). For biological reactions, the Hill coefficient is a parameter used to reflect the steepness of dose-response curves; the higher the Hill coefficient, the steeper the curvature and vice versa. It has been shown that Hill coefficients could further give an idea of the number of either receptors or ligands involved in inhibitor binding. A Hill coefficient of 1 is indicative of a response elicited by the binding of a single ligand to a single receptor, while Hill coefficients greater than 1 could indicate the involvement of more than one ligand in binding a receptor or group of receptors [42]. Hill coefficient results from this study thus suggest that there could be a greater variety of ligand-receptor interactions in both the ethyl acetate and ethanol extracts than in the ethanol extract. It should, however, be noted that although the Hill coefficient can serve to reflect the number of ligands or receptors involved in inhibition, it does not indicate the type of binding (either competitive, noncompetitive, ortho-, iso-, or allosteric) involved [42].

Cell migration is fundamental to promoting tumor progression and metastasis [43]. Results from this study show that all extract treatments reduced U2OS percentage wound closure with a statistically significant decrease observed for only the ethanol extract treatment (Figure 4). This shows that E. foeminea extracts reduced the rate by which U2OS cells migrated to close the wound created by the scratch at the beginning of the assay. It is thus probable that E. foeminea extracts negatively influence the molecular machinery involved in U2OS cell migration.

In cancer, bioactive natural compounds have been shown to affect gene expression through modulating key transcription factors and pathways involved in cancer pathology [44]. In osteosarcoma, one such pathway is the Wnt/B-catenin signaling pathway which enhances the transcription of several downstream Wnt-responsive genes such as those involved in the remodeling of the extracellular matrix and in cell cycle regulation when $\mathrm{B}$-catenin is translocated to the nucleus [45]. In this study, E. foeminea extracts downregulated $B$ catenin steady-state mRNA expression (Figures 4(a), 4(b), and S3 and Table 2), suggesting a decline in the amounts of 


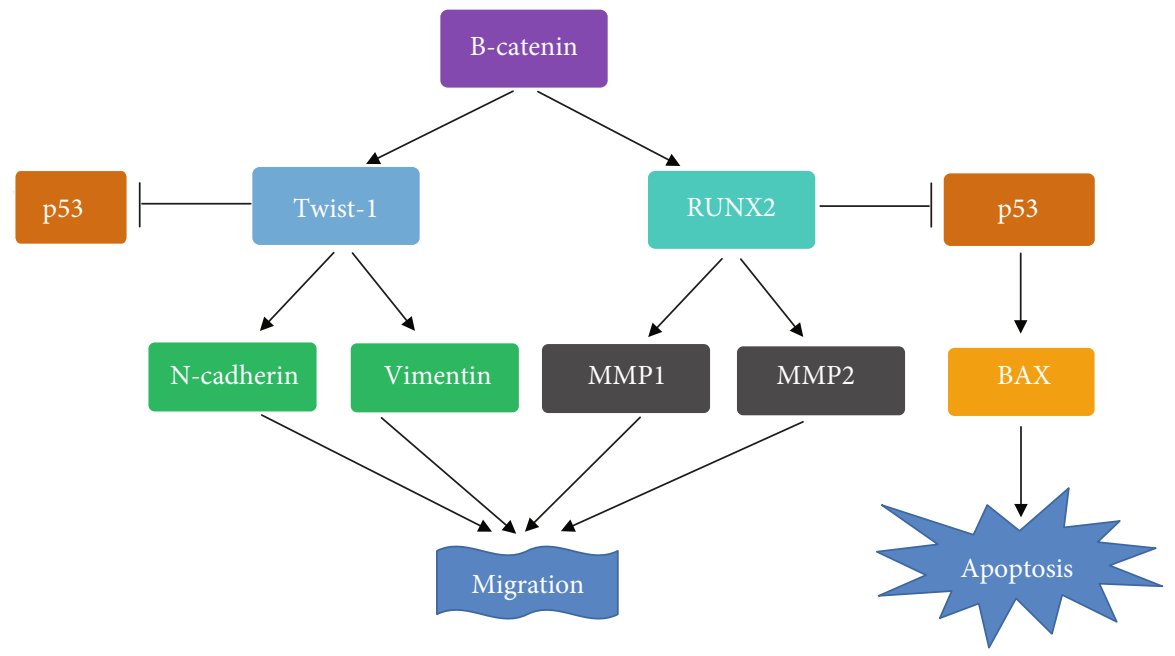

FIGURE 8: Depicted effect of E. foeminea extracts on U2OS gene expression. E. foeminea downregulated the steady-state mRNA expression of markers involved in cell proliferation, migration, and apoptosis. By downregulating the steady-state mRNA expression of both B-catenin and p53, downstream markers of cell proliferation, migration, and apoptosis are, respectively, downregulated.

B-catenin protein and thus a subsequent decrease in the expression of downstream WNT-responsive genes. A number of studies have previously shown that several compounds of natural origin can modulate the Wnt/B-catenin signaling pathway. Curcumin was shown to suppress Wnt/B-catenin signaling by activating both Oct4 and glycogen synthase kinase 3B (GSK-3B) in both human embryonic kidney 293T cells and NCCIT human embryonic carcinoma cells. Further still, curcumin mitigated cell invasion, migration, and proliferation in U2OS, SaOS-2, and HOS osteosarcoma cells via Wnt/B-catenin suppression [44].

Both Twist-1 and RUNX2 expression is activated by the Wnt/B-catenin signaling pathway [46, 47]. Triggered expression of RUNX2 by Wnt/B-catenin signaling was shown to promote the expression of several genes such as MMP1 and $M M P 2$ that promote cell migration and metastasis in osteosarcoma by remodeling the extracellular matrix $[46,48]$. In addition, Twist- 1 activation has been implicated in many cancers in which it promotes the expression of several genes involved in angiogenesis chemoresistance, stemness, and metastasis [47]. Twist-1 has been shown to promote the expression of both $N$-cadherin and vimentin whose expression has been associated with increased migratory and invasive ability in several cancers. It is thus possible that the downregulation of B-catenin by E. foeminea, in turn, leads to decreased expression of both Twist-1 and RUNX2 transcription factors which subsequently reduces the expression of their downstream targets that in reference to this study include $N$-cadherin, vimentin, $M M P 1$, and $M M P 2$ (Figure 5, Figure S3, and Table 2).

E. foeminea treatments downregulated proapoptotic markers $p 53$ and $B A X$ as well (Figure 5, Figure S3). Since both Twist-1 and RUNX2 are inhibitors of p53-mediated apoptosis [5, 47], it was expected that their downregulation would cause an upregulation of p53. This was not the case, however, since p53 expression was shown to be downregulated in E. foeminea treatments. It is thus probable that in addition to targeting the Wnt/B-catenin pathway, $E$. foeminea independently targets the p53-mediated apoptotic pathway by downregulating $p 53$ and subsequently downregulating $B A X$. A schematic representation of the proposed path by which E. foeminea crude extract treatments downregulate migration markers (MMP1, MMP2, N-cadherin, and vimentin) along with proapoptotic markers ( $p 53$ and $B A X)$ is shown in Figure 8. Effect on gene expression is mostly dependent on the lipophilicity of a ligand, which determines whether the ligand directly crosses the cell membrane or instead binds to a transmembrane receptor and hence affects signal transduction cascades [49]. The more polar extracts such as water and ethanol probably contain more lipophobic ligands that likely bind to membrane receptor(s), most probably a $\mathrm{G}$ protein-coupled receptor or a receptor tyrosine kinase [50].

It is not uncommon for chemotherapeutic drugs to modulate gene expression [51-53]; doxorubicin, a standard chemotherapeutic drug against osteosarcoma [54], is a nonspecific drug that stops replication by preventing DNA cut by topoisomerase II from being resealed. It may also increase free radical production, hence adding to its cytotoxicity. Finally, it is also known to intercalate between base pairs, inducing histone eviction from transcriptionally active chromatin [54]. Nutlin-3 is an imidazoline analog that disrupts the interaction between p53 and MDM2, resulting in a growth inhibition state called senescence. Nutlin-3 works best on tumors that contain wild-type p53 and has been shown to exert its effect within minutes after treatment [55].

U2OS gene expression when treated with either E. foeminea, doxorubicin, or nutlin-3 was assessed (Figure 6, Table 3$)$. Only one gene (RUNX2) out of nine was significantly downregulated by all the three treatments; it is possible that RUNX2 could be a potent therapeutic target in osteosarcoma treatment [46]. Both B-catenin and $N$-cadherin were downregulated by $E$. foeminea and doxorubicin but not nutlin-3; Twist-1 was however downregulated by both $E$. foeminea and nutlin-3 but not doxorubicin. It is also worth noting that both MMP1 and MMP2 were exclusively 
downregulated by E. foeminea, indicating that E. foeminea probably reduces extracellular matrix remodeling by downregulating MMPs and thus decreasing cell migration.

The ability of E. foeminea extracts to lyse normal human erythrocytes was negligible (Figure 7). It has been reported that several medicinal plants contain chemical compounds that could promote hemolysis and result in adverse conditions such as hemolytic anemia. It is thus critical that medicinal plants are tested for possible hemolytic potential [56]. Our results indicate that E. foeminea extracts exhibit minute hemolytic activity and are likely cytocompatible with human erythrocytes even at concentrations greater than $\mathrm{IC}_{50}$ [57].

\section{Conclusions}

Taken together, this study shows that E. foeminea extracts significantly reduce $\mathrm{U} 2 \mathrm{OS}$ cell viability and migration. All extracts downregulated the steady-state mRNA expression of key markers involved in regulating these processes. Finally, E. foeminea extracts exhibited negligible hemolytic activity.

It seems clear that E. foeminea ethyl acetate, ethanol, and water extracts contain different phytoconstituents with different cytotoxicities; chemical profiling, analysis of active extracts, and identification of compounds using methods such as high-performance liquid chromatography (HPLC), liquid chromatography-mass spectrometry (LC-MS), and/or gas chromatography-mass spectroscopy (GCMS) are recommended.

\section{Data Availability}

The biological activity data used to support the findings of this study are included both within the article and in the supplementary material. All microarray datasets used in this study were obtained from the Gene Expression Omnibus (GEO) database, and all accession numbers are included in Table S2 in the supplementary material. Inquiries regarding raw data used in this study can be made through the corresponding author, Asma Amleh; aamleh@aucegypt.edu.

\section{Disclosure}

The institution had no involvement in conducting this research.

\section{Conflicts of Interest}

The authors declare that there is no conflict of interest regarding the publication of this paper.

\section{Acknowledgments}

Grants provided by the American University in Cairo (AUC) supported this work.

\section{Supplementary Materials}

Figure S1. U2OS growth curve as determined over a 6-day period. The growth curve exhibited a sigmoid pattern with lag, exponential and statinary phases. Figure S2: Effect of E. foeminea ethyl acetate, ethanol and water extract treatments on U2OS cell morphology. Cells mostly possessed an elliptical shape in which they appeared wider at the center with tapering ends (red circles). Table S1. RT-PCR Forward (F) and Reverse (R) Primer Sequences, Annealing Temperature, Cycle Number and Amplicon Sizes.Table S2. Microarray Dataset Table S3. Summary of MTT assay Pvalues obtained for all extract treatments. Supplementary File 1.Fold change values of genes after doxorubicin treatment. Supplementary File 2.Fold change values of genes after nutlin treatment. (Supplementary Materials)

\section{References}

[1] WHO | Cancerhttp://www.who.int/mediacentre/factsheets/ fs297/en/.

[2] S.-X. Dai, W.-X. Li, F.-F. Han et al., "In silico identification of anti-cancer compounds and plants from traditional Chinese medicine database," Scientific Reports, vol. 6, no. 1, article srep25462, 2016.

[3] American Cancer Society, "What is osteosarcoma?," https:// www.cancer.org/cancer/osteosarcoma/about/what-isosteosarcoma.html.

[4] ATCC ATCC, "U-2 OS ATCC ${ }^{\circledR}$ HTB-96 ${ }^{\mathrm{TM}}$ Homo sapiens bone osteosarcoma," https://www.atcc.org/Products/All/ HTB-96.aspx.

[5] E. S. Kleinerman, Current Advances in Osteosarcoma, Springer, New York, NY, USA, 2014.

[6] C. M. J. Lucero, O. A. Vega, M. M. Osorio et al., "The cancerrelated transcription factor Runx2 modulates cell proliferation in human osteosarcoma cell lines," Journal of Cellular Physiology, vol. 228, no. 4, pp. 714-723, 2013.

[7] J. Pratap, M. Galindo, S. K. Zaidi et al., "Cell growth regulatory role of Runx2 during proliferative expansion of preosteoblasts," Cancer Research, vol. 63, no. 17, pp. 5357-5362, 2003.

[8] L. Sun, M. I. Vitolo, M. Qiao, I. E. Anglin, and A. Passaniti, "Regulation of TGF $\beta_{1}$-mediated growth inhibition and apoptosis by RUNX2 isoforms in endothelial cells," Oncogene, vol. 23, no. 27, pp. 4722-4734, 2004.

[9] S. Elmore, "Apoptosis: a review of programmed cell death," Toxicologic Pathology, vol. 35, no. 4, pp. 495-516, 2016.

[10] M. Oren, "Decision making by p53: life, death and cancer," Cell Death and Differentiation, vol. 10, no. 4, pp. 431-442, 2003.

[11] A. J. Teodoro, "Bioactive compounds of food: their role in the prevention and treatment of diseases," Oxidative Medicine and Cellular Longevity, vol. 2019, Article ID 3765986, 4 pages, 2019.

[12] A. Mollica, G. Zengin, A. Stefanucci et al., "Nutraceutical potential of Corylus avellana daily supplements for obesity and related dysmetabolism," Journal of Functional Foods, vol. 47, pp. 562-574, 2018.

[13] A. G. Atanasov, S. M. Sabharanjak, G. Zengin et al., "Pecan nuts: a review of reported bioactivities and health effects," Trends in Food Science and Technology, vol. 71, pp. 246-257, 2018.

[14] E. Safarzadeh, S. Sandoghchian Shotorbani, and B. Baradaran, "Herbal medicine as inducers of apoptosis in cancer treatment," Advanced Pharmaceutical Bulletin, vol. 4, Supplement 1, pp. 421-427, 2014. 
[15] A. Mukherjee, S. Basu, N. Sarkar, and A. Ghosh, "Advances in cancer therapy with plant based natural products," Current Medicinal Chemistry, vol. 8, no. 12, pp. 1467-1486, 2001.

[16] H. Freitag and M. Maier-Stolte, "THEEPHEDRA-SPECIES of P. Forsskål: identity and typification," Taxon, vol. 38 , no. 4, pp. 545-556, 2019.

[17] M. Maglione, K. Miotto, M. Iguchi, L. Jungvig, S. C. Morton, and P. G. Shekelle, "Psychiatric effects of ephedra use: an analysis of Food and Drug Administration reports of adverse events," The American Journal of Psychiatry, vol. 162, no. 1, pp. 189-191, 2005.

[18] S. Ibragic and E. Sofic, "Chemical composition of various Ephedra species," Bosnian Journal of Basic Medical Sciences, vol. 15, no. 3, pp. 21-27, 2015.

[19] E. Ben-Arye, J. Mahajna, R. Aly et al., "Exploring an herbal 'wonder cure' for cancer: a multidisciplinary approach," Journal of Cancer Research and Clinical Oncology, vol. 142, no. 7, pp. 1499-1508, 2016.

[20] M. Maayan, S. Monick, F. Marcelo et al., "Effect of Ephedra foeminea active compounds on cell viability and actin structures in cancer cell lines," Journal of Medicinal Plants Research, vol. 11, no. 43, pp. 690-702, 2017.

[21] Q.-W. Zhang, L.-G. Lin, and W.-C. Ye, "Techniques for extraction and isolation of natural products: a comprehensive review," Chinese Medicine, vol. 13, no. 1, p. 20, 2018.

[22] T. Dhanani, S. Shah, N. A. Gajbhiye, and S. Kumar, "Effect of extraction methods on yield, phytochemical constituents and antioxidant activity of Withania somnifera," Arabian Journal of Chemistry, vol. 10, pp. S1193-S1199, 2017.

[23] V. Kuete, Medicinal spices and vegetables from Africa: therapeutic potential against metabolic, inflammatory, infectious and systemic diseases, Academic Press, an imprint of Elsevier, Amsterdam, 2017.

[24] E. Z. Mpingirika and A. Amleh, "The effect of Ephedra foeminea on human bone osteosarcoma U2OS cell viability and migration," 2019, http://dar.aucegypt.edu/handle/10526/5589.

[25] A. T. C. C. ATCC, AnimCellCulture_Guide.pdf, 2014, http:// www.lgcstandards-atcc.org/Guides.aspx?geo_country=eg.

[26] T. L. Riss, R. A. Moravec, A. L. Niles et al., "Cell viability assays," in Assay Guidance Manual, G. S. Sittampalam, N. P. Coussens, K. Brimacombe, A. Grossman, M. Arkin, D. Auld, C. Austin, J. Baell, B. Bejcek, J. M. M. Caaveiro, T. D. Y. Chung, J. L. Dahlin, V. Devanaryan, T. L. Foley, M. Glicksman, M. D. Hall, J. V. Haas, J. Inglese, P. W. Iversen, S. D. Kahl, S. C. Kales, M. Lal-Nag, Z. Li, J. McGee, O. McManus, T. Riss, O. J. Trask, J. R. Weidner, M. J. Wildey, M. Xia, and X. Xu, Eds., Eli Lilly \& Company and the National Center for Advancing Translational Sciences, Bethesda, MD, USA, 2004.

[27] C. A. Schneider, W. S. Rasband, and K. W. Eliceiri, "NIH Image to ImageJ: 25 years of image analysis," Nature Methods, vol. 9, no. 7, pp. 671-675, 2012.

[28] A. I. Boleman, G. Tănasie, A. Găluşcan et al., "Studies regarding the in vitro wound healing potential of mouse dental pulp stem-like progenitor cells," Biotechnology and Biotechnological Equipment, vol. 26, no. 1, pp. 2781-2785, 2014.

[29] D. Menendez, T.-A. Nguyen, J. M. Freudenberg et al., "Diverse stresses dramatically alter genome-wide p53 binding and transactivation landscape in human cancer cells," Nucleic Acids Research, vol. 41, no. 15, pp. 7286-7301, 2013.

[30] 2017, Colin A. Smith <Colin@Colinsmith.Org>: "annaffy," https://bioconductor.org/packages/annaffy.
[31] D. Malagoli, "A full-length protocol to test hemolytic activity of palytoxin on human erythrocytes," Invertebrate Survival Journal, vol. 4, no. 2, pp. 92-94, 2007.

[32] Graphpad Software Inc, GraphPad Prism version 6.01 for WindowsGraphPad Software, La Jolla, CA, USAhttps://www .graphpad.com.

[33] M. Zohra and A. Fawzia, "Hemolytic activity of different herbal extracts used in Algeria," International Journal of Pharma Sciences and Research, vol. 5, no. 8, p. 6, 2014.

[34] I. Assanga, "Cell growth curves for different cell lines and their relationship with biological activities," International Journal of Biotechnology and Molecular Biology Research, vol. 4, no. 4, pp. 60-70, 2013.

[35] L. Rey, J. M. Sidorova, N. Puget et al., "Human DNA polymerase $\eta$ is required for common fragile site stability during unperturbed DNA replication," Molecular and Cellular Biology, vol. 29, no. 12, pp. 3344-3354, 2009.

[36] K. Al-Romaih, G. R. Somers, J. Bayani et al., "Modulation by decitabine of gene expression and growth of osteosarcoma U2OS cells in vitro and in xenografts: identification of apoptotic genes as targets for demethylation," Cancer Cell International, vol. 7, no. 1, p. 14, 2007.

[37] F. Denizot and R. Lang, "Rapid colorimetric assay for cell growth and survival: Modifications to the tetrazolium dye procedure giving improved sensitivity and reliability," Journal of Immunological Methods, vol. 89, no. 2, pp. 271-277, 1986.

[38] C. De Monte, S. Carradori, A. Granese, G. B. Di Pierro, C. Leonardo, and C. De Nunzio, "Modern extraction techniques and their impact on the pharmacological profile of Serenoa repens extracts for the treatment of lower urinary tract symptoms," BMC Urology, vol. 14, no. 1, 2014.

[39] S. D. Sarker, Z. Latif, and A. I. Gray, Eds., Natural Products Isolation, Humana Press, Totowa, NJ, USA, 2005.

[40] D. Carrle and S. S. Bielack, "Current strategies of chemotherapy in osteosarcoma," International Orthopaedics, vol. 30, no. 6, pp. 445-451, 2006.

[41] P. Rasoanaivo, C. W. Wright, M. L. Willcox, and B. Gilbert, "Whole plant extracts versus single compounds for the treatment of malaria: synergy and positive interactions," Malaria Journal, vol. 10, Supplement 1, p. S4, 2011.

[42] H. Prinz, "Hill coefficients, dose-response curves and allosteric mechanisms," Journal of Chemical Biology, vol. 3, no. 1, pp. 37-44, 2010.

[43] F. Entschladen, T. L. Drell, K. Lang, J. Joseph, and K. S. Zaenker, "Tumour-cell migration, invasion, and metastasis: navigation by neurotransmitters," The Lancet Oncology, vol. 5, no. 4, pp. 254-258, 2004.

[44] M. K. Shanmugam, J. H. Lee, E. Z. P. Chai et al., "Cancer prevention and therapy through the modulation of transcription factors by bioactive natural compounds," Seminars in Cancer Biology, vol. 40-41, pp. 35-47, 2016.

[45] C. Kong and M. F. Hansen, "Biomarkers in osteosarcoma," Expert Opinion on Medical Diagnostics, vol. 3, no. 1, pp. 1323, 2008.

[46] J. Pratap, J. B. Lian, A. Javed et al., "Regulatory roles of Runx2 in metastatic tumor and cancer cell interactions with bone," Cancer Metastasis Reviews, vol. 25, no. 4, pp. 589-600, 2006.

[47] Z. Zhao, M. A. Rahman, Z. G. Chen, and D. M. Shin, "Multiple biological functions of Twist1 in various cancers," Oncotarget, vol. 8, no. 12, pp. 20380-20393, 2017. 
[48] O. A. Vega, C. M. J. Lucero, H. F. Araya et al., "Wnt/ $\beta$-catenin signaling activates expression of the bone-related transcription factor RUNX2 in select human osteosarcoma cell types," Journal of Cellular Biochemistry, vol. 118, no. 11, pp. 3662-3674, 2017.

[49] W. R. Bidlack and R. L. Rodriguez, Nutritional Genomics: the Impact of Dietary Regulation of Gene Function on Human Disease, CRC Press/Taylor \& Francis Group, Boca Raton, 2012.

[50] S. Gilbert, Developmental Biology, Sinauer Associates, Sunderland, MA, USA, 6th edition, 2000, Cell surface receptors and their signal transduction pathways, https://www.ncbi.nlm.nih .gov/books/NBK10043/.

[51] P. Estevez-Garcia, F. Rivera, S. Molina-Pinelo et al., "Gene expression profile predictive of response to chemotherapy in metastatic colorectal cancer," Oncotarget, vol. 6, no. 8, pp. 6151-6159, 2015.

[52] D. Hui, N. Satkunam, M. Al Kaptan, T. Reiman, and R. Lai, "Pathway-specific apoptotic gene expression profiling in chronic lymphocytic leukemia and follicular lymphoma," Modern Pathology, vol. 19, no. 9, pp. 1192-1202, 2006.

[53] E. L. Korn, L. M. McShane, J. F. Troendle, A. Rosenwald, and R. Simon, "Identifying pre-post chemotherapy differences in gene expression in breast tumours: a statistical method appropriate for this aim," British Journal of Cancer, vol. 86, no. 7, pp. 1093-1096, 2002.

[54] S. M. Blaney, M. A. Smith, and J. L. Grem, "Doxorubicin: role in the treatment of osteosarcoma," in Osteosarcoma in Adolescents and Young Adults: New Developments and Controversies. Cancer Treatment and Research, vol 62Springer, Boston, MA, USA.

[55] I. Haaland, J. A. Opsahl, F. S. Berven et al., "Molecular mechanisms of nutlin-3 involve acetylation of p53, histones and heat shock proteins in acute myeloid leukemia," Molecular Cancer, vol. 13, no. 1, p. 116, 2014.

[56] J. Dima, L. Raghda, and G. Abdul-Jalil, "Evaluation of hemolytic and anti-hemolytic activity of the aerial parts of Sonchus oleraceus extracts," International Journal of Pharmaceutical Sciences and Nanotechnology, vol. 10, no. 3, p. 7, 2017.

[57] B. C. Evans, C. E. Nelson, S. S. Yu et al., "Ex vivo red blood cell hemolysis assay for the evaluation of $\mathrm{pH}$-responsive endosomolytic agents for cytosolic delivery of biomacromolecular drugs," Journal of Visualized Experiments, vol. 73, article e50166, 2013. 